\title{
760 prac dyplomowych na temat gier komputerowych wykonanych w 11 polskich uniwersytetach do wiosny 2019
}

760 Bachelor and Master Theses on Computer Games

Made at Eleven Polish Universities Until Spring of 2019

\section{Jacek Szymala}

Uniwersytet Wroctawski | historiawkinie@gmail.com | ORCID: 0000-0002-8714-7114

DOI: $10.14746 / \mathrm{hl} .2019 .12 .15$ | received: 31.12 .2018 | accepted: 4.12 .2019

Sugestię, że prace dyplomowe niosą w sobie olbrzymi potencjał badawczy i powinny być katalogowane i udostępniane, nawet niekoniecznie dzięki drukowanym zestawieniom, wysunął już 15 lat temu Józef Andrzej Gierowski w krótkim referacie podsumowującym pierwszą konferencję wrocławskich historyków nowożytności, z cyklu „Staropolski ogląd świata" (Gierowski, 2004, s. 396). Wspominał, że z badaniami dotyczącymi historii mentalności zetknął się w 1959 r. w Paryżu, a następnie wprowadził je (m.in. sugerując tematy prac studentom) na Uniwersytecie Jagiellońskim i Uniwersytecie Wrocławskim:

W sumie powstało w ten sposób kilkadziesiąt prac magisterskich, które w najlepszym razie leżą w archiwach Uniwersyteckich lub po domach magistrów, a tylko niewielka ich część została w formie artykułów wydrukowana [...]. Może warto byłoby je zinwentaryzować, by ułatwić pracę późniejszym badaczom. Nie dotyczy to rozpraw doktorskich, które na ogół bywają drukowane [...]. A może już czas pomyśleć o bardziej ogólnym 
inwentarzu (czy bibliografii) prac dotyczącyh mentalności polskiej lub raczej ludności zamieszkującej ziemie Rzeczypospolitej? Przy dzisiejszych udoskonaleniach technicznych inwentarz taki nie musiałby być drukowany (tamże).

W momencie publikacji przywołanych słów zarówno rynek, jak i refleksja badawcza dotycząca gier komputerowych dopiero nabierały rozmachu. Zaczęły także powstawać w kraju pierwsze prace dyplomowe na ten temat. Po upływie półtorej dekady można już nabrać obiektywnego dystansu i spróbować odpowiedzieć na apel Gierowskiego.

Prezentowane zestawienie bibliograficzne stanowi rezultat autorskiego projektu dotyczącego uporządkowania takich prac dyplomowych, które napisane zostały w państwowych uniwersytetach, a w słowach kluczowych zawierają określenie "gry komputerowe”. Jako że nie wszystkie uczelnie prowadzą internetowe Archiwum Prac Dyplomowych', badania ograniczyłem do 11 ośrodków dysponujących taką bazą. Są to: Uniwersytet Śląski (216 prac) $)^{2}$, Uniwersytet Warszawski (139 prac), Uniwersytet im. Adama Mickiewicza w Poznaniu (99 prac), Uniwersytet Mikołaja Kopernika w Toruniu (87 prac), Uniwersytet Wrocławski (53 prace), Uniwersytet Marii-Curie Skłodowskiej w Lublinie (44 prace), Uniwersytet Opolski ( 35 prac), Uniwersytet Warmińsko-Mazurski (29 prac), Uniwersytet im. Kazimierza Wielkiego w Bydgoszczy (28 prac), Uniwersytet Łódzki (22 prace), Uniwersytet Humanistyczno-Przyrodniczy im. Jana Długosza (8 prac). Łącznie w wymienionych uniwersytetach do wiosny 2019 powstało zatem przynajmniej 760 prac dyplomowych dotyczących gier komputerowych.

Rozpraw ukończonych w uczelniach klasyfikowanych jako techniczne (np. politechniki) nie uwzględniłem. Niektóre z nich również korzystają z systemu Archiwum Prac Dyplomowych, jednak nie pojawiło się tam zbyt

1 Z innych systemów archiwizacji prac korzystają m.in. następujące uniwersytety: Uniwersytet Zielonogórski, Uniwersytet Gdański, Uniwersytet Szczeciński, Uniwersytet Pedagogiczny w Krakowie, Katolicki Uniwersytet Lubelski, Uniwersytet Jana Kochanowskiego w Kielcach.

2 Dane w nawiasie obrazują stan na koniec marca 2019. Przykładowo, na Uniwersytecie Śląskim po pół roku (weryfkacja z końcem września 2019) liczba wzrosła z 216 do 234 , czyli o ok. $8 \%$. Jeśli we wszystkich uczelniach nastąpił proporcjonalny przyrost prac o tematyce gier komputerowych, jesienią 2019 mamy przynajmniej $760+60$, tzn. 820 prac w sumie. 
wiele takich przypadków (przykładowo, na Politechnice Warszawskiej 8 prac; na Politechnice Białostockiej - 15). Nie wziąłem pod uwagę także dokonań adeptów uczelni artystycznych (akademie sztuk pięknych, wyższe szkoły plastyczne, muzyczne itd.), gdyż choćby Akademia Muzyczna im. Karola Lipińskiego we Wrocławiu, niekorzystająca z systemu APD, nie ma w swym katalogu żadnej pracy tytułem zapowiadającej problematykę gier komputerowych. Ze względu na powyższe można przyjąć, że w wykazie ująłem większość polskich prac dyplomowych na temat gier komputerowych (760 z ponad 1000). Nawet jeśli założenie to jest mylne, z pewnością przedstawiony zbiór ma charakter reprezentatywny i daje pogląd na tematy prac o tych grach.

Ze względu na to, że nie trzeba już współcześnie przekonywać, iż gry komputerowe stanowią pełnoprawny przedmiot badań, głównym celem jest nie zwrócenie uwagi na te badania, ale raczej zorientowanie badaczy, w tym kierujących pracami dyplomowymi oraz studentów, zwłaszcza przed wybraniem tematu, na już istniejące prace licencjackie, inżynierskie i magisterskie podejmujące tę tematykę. Zestawienie służyć zatem powinno rozwojowi nauki. Często bowiem, co widać na poniższej liście, dochodzi do sytuacji wyważania otwartych drzwi - tematyka prac się powtarza, niejednokrotnie nawet w jednym ośrodku; powstają one niezależnie, a energia, która mogła być skierowana na eksplorację aspektów dotąd niepodjętych, marnowana jest na to, co już wcześniej opracowano.

Zasadność podjęcia tego tematu wynika również z rosnącego zainteresowania problematyką gier komputerowych i z malejących w związku z tym szans na uporządkowanie materiału przez jednego badacza. Spodziewać się można dalszego wzrostu liczby prac dyplomowych zawierających w słowach kluczowych „gry komputerowe”. Ponadto postęp technologiczny pozwala żywić nadzieję na rozszerzenie jednolitego systemu archiwizowania prac dyplomowych także na inne ośrodki. Potrzebna jest też aplikacja pozwalająca na bardziej zaawansowane filtrowanie danych. Powstałe w tym celu Ogólnopolskie Repozytorium Pisemnych Prac Dyplomowych (ORPPD) obecnie nie umożliwia jeszcze przeglądania tytułów rozpraw i funkcjonuje jako system antyplagiatowy.

Aby zwiększyć czytelność zestawienia, przyjąłem system zapisywania podobny jak w przypadku tomów zbiorowych, a więc rozpoczynając od tytułów. Zrezygnowałem z podawania nazwisk autorów, ograniczając się 
do wymienienia promotorów. W przeważającej mierze tytuły wystarczająco informują o zawartości prac. Argumentem za ukryciem tożsamości twórców jest zawarty w instrukcji do archiwizowania rozpraw zapis o „ukryciu własnego nazwiska przez autora pracy”. Za takim rozwiązaniem przemawia też to, że nazwiska promotorów są lepiej znane badaczom, po studiach pierwszego stopnia zaś nie zawsze kontynuuje się naukę. Jeszcze rzadziej absolwenci studiów licencjackich zostają samodzielnymi naukowcami (a jeśli nawet by się tak działo, to dopiero po latach, czyli sporo po publikacji tego zestawienia). Ponadto nie w każdym przypadku zatwierdzenie tematu rozprawy jest tożsame z jej napisaniem, a zwłaszcza obroną (w zestawieniu podane są daty roczne wykonania, tj. złożenia prac, w tym także tych, które otrzymały negatywne recenzje). Co więcej, kontakt z promotorem danej pracy to jedna z możliwości uzyskania dostępu do niej (alternatywę stanowi kontakt z administratorem archiwum lub udanie się do odpowiedniego katalogu kartkowego biblioteki/archiwum).

Zastosowałem szereg skrótów, których wyjaśnienie znajduje się poniżej. Zrezygnowałem także z podawania nazw uczelni, zamiast tego wypisałem tylko miejsca: prace napisane w Cieszynie, Chorzowie, Katowicach i Sosnowcu należą do Uniwersytetu Śląskiego; te z Opola - do Uniwersytetu Opolskiego; z Łodzi - do Uniwersytetu Łódzkiego; z Bydgoszczy - do Uniwersytetu im. Kazimierza Wielkiego; z Krakowa - do Uniwersytetu Jagiellońskiego; z Poznania lub Kalisza - do Uniwersytetu im. Adama Mickiewicza; z Lublina - do Uniwersytetu Marii Curie-Skłodowskiej; z Olsztyna - do Uniwersytetu Warmińsko-Mazurskiego; z Torunia - do Uniwersytetu Mikołaja Kopernika; z Warszawy - do Uniwersytetu Warszawskiego; a te z Wrocławia - do Uniwersyteta Wrocławskiego ${ }^{4}$.

Najbardziej ogólną konkluzją, do jakiej skłania zestawienie, jest to, że pracownicy naukowi wciąż niechętnie i rzadko powołują się na ustalenia zawarte w pracach magisterskich i - zwłaszcza - licencjackich oraz inżynierskich. Niewykluczone, iż wynika to głównie z przekonania o ich

3 Spośród wszystkich wymienionych ośrodków tylko katalog prac wykonanych w Uniwersytecie Jagiellońskim nie umożliwia wyszukiwania zaawansowanego, a jedynie szybkie, co powoduje niekompletność wykazu.

4 W przeciwieństwie do innych internetowe archiwum prac wykonanych na Uniwersytecie Wrocławskim jest dostępne tylko dla zalogowanych użytkowników. 
niskim poziomie merytorycznym lub z obaw, że mają one odtwórczy charakter (i/lub wręcz nieufności względem sumienności ich wykonania), można jednak przyjąć też hipotezę, że są one po prostu nieznane badaczom. Trzeba także zauważyć naganną praktykę, gdy promotor jest zarazem jednym z recenzentów pracy (a czasami jedynym) (przynajmniej tak wynika z katalogów). Należy mieć nadzieję, że - także dzięki temu zestawieniu - opisane sytuacje ulegną zmianie, zwłaszcza ze względu na dynamikę problemu badawczego: wiele wymienionych rozpraw powstało w ostatniej dekadzie. Analiza ich tytułów, a tym bardziej ich treści, wymaga badań zakrojonych na szerszą skalę.

\section{Literatura}

Gierowski, J. A. (2004). Kilka uwag o staropolskim oglądzie świata. W: B. Rok, F. Wolański (red.), Staropolski ogląd świata. Materiaty z konferencji, Wrocław 23-24 października 2004 r. (s. 395-397). Wrocław: Instytut Historyczny Uniwersytetu Wrocławskiego.

PTBG (2019). 760 prac dyplomowych na temat gier komputerowych wykonanych w 11 polskich uniwersytetach do wiosny 2019. Online: <https:// www.ptbg.org.pl/publikacje/>. Data dostępu: 23 stycznia 2019.

${ }^{5}$ Pełen wykaz prac - zob. PTBG (2019).

dr Jacek Szymala - historyk i kulturoznawca, ostatnio zajmuje się performatywnym aspektem gier komputerowych oraz dziejami polskich wypraw polarnych. Autor książek: Film - Historia - Turystyka (2016) oraz Powstanie kozackie 1648-1658. Studium z historii wizualnej (2019). Wspótredaktor tomu Film a historia. Szkice z dziejów wizualnych (2019). Autor kilkunastu artykułów naukowych. Odnalazt filmowy reportaż Do Ziemi Torella, reż. W. Biernawski, 1934. Członek Polskiego Towarzystwa Badań nad Filmem i Mediami oraz Polskiego Towarzystwa Badania Gier. Wykładowca Akademii Polskiego Filmu 